\title{
Frequent burning promotes invasions of alien plants into a mesic African savanna
}

\author{
Mhosisi Masocha $\cdot$ Andrew K. Skidmore • \\ Xavier Poshiwa $\cdot$ Herbert H. T. Prins
}

Received: 31 August 2009/Accepted: 27 November 2010/Published online: 11 December 2010

(C) The Author(s) 2010. This article is published with open access at Springerlink.com

\begin{abstract}
Fire is both inevitable and necessary for maintaining the structure and functioning of mesic savannas. Without disturbances such as fire and herbivory, tree cover can increase at the expense of grass cover and over time dominate mesic savannas. Consequently, repeated burning is widely used to suppress tree recruitment and control bush encroachment. However, the effect of regular burning on invasion by alien plant species is little understood. Here, vegetation data from a long-term fire experiment, which began in 1953 in a mesic Zimbabwean savanna, were used to test whether the frequency of burning promoted alien plant invasion. The fire treatments consisted of late season fires, lit at 1-, 2-, $3-$, and 4-year intervals, and these regularly burnt
\end{abstract}

\section{Masocha ( $\square)$}

Department of Geography and Environmental Science, University of Zimbabwe, Box MP 167, Mount Pleasant, Harare, Zimbabwe

e-mail: mmasocha@science.uz.ac.zw

\section{A. K. Skidmore}

Department of Natural Resources, Faculty of GeoInformation Science and Earth Observation, University of Twente, Box 6, 7500 AA Enschede, The Netherlands

\section{Poshiwa}

Grasslands Research Station, Private Bag 3701, Marondera, Zimbabwe

\section{H. H. T. Prins}

Resource Ecology Group, Wageningen University, Box 47, 6700 AA Wageningen, The Netherlands plots were compared with unburnt plots. Results show that over half a century of frequent burning promoted the invasion by alien plants relative to areas where fire was excluded. More alien plant species became established in plots that had a higher frequency of burning. The proportion of alien species in the species assemblage was highest in the annually burnt plots followed by plots burnt biennially. Alien plant invasion was lowest in plots protected from fire but did not differ significantly between plots burnt triennially and quadrennially. Further, the abundance of five alien forbs increased significantly as the interval (in years) between fires became shorter. On average, the density of these alien forbs in annually burnt plots was at least ten times as high as the density of unburnt plots. Plant diversity was also altered by long-term burning. Total plant species richness was significantly lower in the unburnt plots compared to regularly burnt plots. These findings suggest that frequent burning of mesic savannas enhances invasion by alien plants, with short intervals between fires favouring alien forbs. Therefore, reducing the frequency of burning may be a key to minimising the risk of alien plant spread into mesic savannas, which is important because invasive plants pose a threat to native biodiversity and may alter savanna functioning.

Keywords Exotic forbs - Fire - Long-term fire experiment - Marondera grasslands research station . Savanna burning $\cdot$ Zimbabwe 


\section{Introduction}

Fire is one of the major factors controlling vegetation structure, composition, and dynamics as well as ecosystem functioning in mesic African savannas, which receive more than $650 \mathrm{~mm}$ of annual precipitation (Bond et al. 2005; Sankaran et al. 2005; Savadogo et al. 2008). Without disturbances such as fire or grazing, tree cover can increase at the expense of grass cover and dominate these mesic savannas (Higgins et al. 2000; Van Langevelde et al. 2003). Because tree-grass coexistence is essential for savanna functioning, managers of these savannas use fire to control bush encroachment (Govender et al. 2006). The use of fire to manage savannas is justified by managers on the grounds that savanna vegetation evolved in the presence of fire and is thus adapted to, or tolerant of, fire (Bond and Midgley 2001). However, despite decades of research, there is still uncertainty and disagreement among ecologists regarding the appropriate fire regimes natural resource managers should employ to manage savannas (Van Wilgen et al. 2004).

For example, based on current understanding of the relationship between fire intensity, its frequency and tree mortality, some ecologists prescribe regular burning during the dry season to limit tree recruitment and control bush encroachment (Roques et al. 2001). Other fire ecologists, however, suggest that the imposition of regular fires of similar intensity can lead to the dominance of grasses. Hence these ecologists recommend fires of variable intensities, and they further stress that flexible burning is required to promote tree-grass coexistence (Bond and Archibald 2003). At present, regular burning remains the most popular tool for managing savannas, despite the fact that the effects of fire frequency on species composition are little understood. Frequent fires in savanna ecosystems may promote invasion by non-indigenous (alien) species, since disturbance is known to increase the invadability of plant communities (Hobbs and Huenneke 1992; Valery et al. 2008). Yet, this issue remains poorly addressed in fire ecology studies.

Empirical evidence suggests that in savannas, different fire regimes promote particular traits in plants (Bond and Keeley 2005; Watson et al. 2009). For example, 'ruderalism', that is, the specialisation associated with a short life cycle and high seed production (Grime 1977), and having pole-like stems are important traits, enabling plants to establish and persist in frequently burnt savannas. These traits are known to facilitate rapid colonisation (Lavorel et al. 1997) and bolting towards a height that is out of reach of surface fires before the next burn (Bond and Keeley 2005).

The purpose of this study is to test the hypotheses that frequent burning of a mesic savanna creates gaps in a plant community suitable for colonisation by alien plants and that short intervals between fires may favour ruderal alien species with a short life span. To test these hypotheses, vegetation data from a longterm fire experiment, which began in 1953 at a mesic Zimbabwean savanna site, were used. The fire treatments applied were annual, biennial, triennial, and quadrennial burning late in the dry season, and these treatments were compared with no burning. This burning experiment was originally designed to assess the effects of fire on tree growth and dominance, but here it is used to shed light on the impact of fire on alien plant invasion, going beyond the original scope of the study, because the treatments have been applied for more than 50 years.

\section{Methods}

Study site

The study was conducted at the Grassland Research Station $\left(18^{\circ} 65^{\prime}\right.$ South, $31^{\circ} 15^{\prime}$ East; altitude 1,630 m), located $8 \mathrm{~km}$ west of Marondera town and about $55 \mathrm{~km}$ southeast of Harare in Zimbabwe. The climate is seasonal with most of the precipitation, averaging $885 \mathrm{~mm}$ per year, falling between October and April. Mean monthly temperatures range from $12.3^{\circ} \mathrm{C}$ in June to $19.7^{\circ} \mathrm{C}$ in October (Grundy et al. 1994). The soils are coarse-grained sandy soils derived from granite (Barnes 1965). The vegetation is deciduous savanna "miombo" woodland with Brachystegia spiciformis and Julbernardia globiflora as the dominant trees. The herbaceous layer is variable in composition, but the dominant grasses are Hyparrhenia filipendula, Melinis minutiflora, and Heteropogon contortus. Botanical nomenclature follows Palgrave (2002) for woody species and Oudtshoorn (Oudtshoorn 2006) for grasses. 
Experimental design

In 1953, experimental burning began at the Grassland Research Station to investigate the response of savanna vegetation to different fire regimes (Barnes 1965). A total of 22 experimental plots each measuring $36 \times 60 \mathrm{~m}$ were established. A 3-m wide firebreak was established around each plot. The experimental site was fenced off to exclude livestock grazing. The fire treatment applied was burning with late-season (August-November) fires lit at 1-, 2-, 3-, and 4-year intervals, to be compared with no burning. The different treatments were replicated as follows: burning once every 4 years (quadrennial burning) was replicated eight times; burning once every 3 years (triennial burning) six times; burning once every 2 years (biennial burning) four times; burning once every year (annual burning) and no burning twice each. Replication was biased in favour of treatments with longer intervals between fires to ensure that for each fire frequency at least one plot was burnt every year. Further details about the history of the experiment and its design can be found in Strang (1974) and Furley et al. (2008).

This fire experiment has been well-maintained for more than 50 years and is still running. However, there were some years, for example 1991 and 1992, when the annual and biennial plots were not burnt according to schedule due to lack of sufficient fuel load caused by an extreme drought that occurred in these years. Similar problems have been reported in the Kruger long-term fire trials (Van Wilgen et al. 2008) but unlike at Kruger national park (South Africa) where attempts to impose a series of fire regimes on 7-ha plots were not entirely successful (Van Wilgen 2009), the Marondera fire experiment has never been disrupted by wildfires.

Vegetation sampling

In March 2007 during the peak growing season, the vegetation was assessed along two diagonal belt transects $(50 \mathrm{~m}$ in length and $5 \mathrm{~m}$ in width) established in each experimental plot. Ten $5 \times 5-\mathrm{m}$ contiguous quadrates were placed along each transect. In each $5 \times 5$-m plot, all woody plants present were identified to species level and their abundance (i.e. number of stems per species) recorded. Herbaceous species were also identified to species level and their density recorded from $1 \times 1-\mathrm{m}$ quadrates placed in the centre of each $5 \times 5$-m plot. Grass and sedge density were recorded as tiller numbers per quadrat, leaf numbers were counted for stoloniferous species e.g. Ipomoea indica, and the number of individual plants per each species for other species (Gibson 1988). For each experimental plot, the density of herbaceous species (number of plants per species per $1 \mathrm{~m}^{2}$ plot) was averaged per species.

To determine whether species identified in the experimental plots were native or aliens (i.e. those not indigenous to southern Africa), national checklists (Mapaura and Timberlake 2004) and regional floras were consulted (Gibbs Russell et al. 1990; Glen 2002; Henderson 2007). The proportion of aliens was calculated as the number of alien plant species present in a given experimental plot divided by the total number of plant species present in that plot.

Data analysis

Treatment means for total number of plant species (overall richness), number of alien plant species (alien richness), number of forbs, number of graminoids (i.e. grasses plus sedges), number of woody species, proportion of alien plant species, and the abundance (i.e. density) of common alien forbs, were compared among the five fire treatments using one-way analysis of variance (ANOVA). Although abundance data were collected for all alien forbs, analysis of individual species response to fire treatments was restricted to five alien forbs present in all the experimental plots. Prior to performing ANOVA, data on the number of species and density of common alien forbs were log-transformed while data on the proportion of alien species were arcsine transformed to generate a normal distribution (Crawley 2002). Following a significant fire treatment effect, Turkey's honestly significantly different (HSD) tests were performed to detect significant pairwise differences between means. $P<0.05$ was used as the critical level of significance. All analyses were performed using Statistica version 7.0 (StatSoft, Inc.).

\section{Results}

Impact of fire on plant diversity and alien richness

A total of 110 vascular plant species were identified in the experimental plots, of which nine were alien 
species. The alien species consisted of seven forbs (namely Aster squamatus, Bidens pilosa, Conyza bonariensis, Desmodium uncinatum, Richardia brasiliensis, Sida cordifolia, and Tagetes minuta) and two woody species (Lantana camara and Jacaranda mimosifolia).

Results show that, plant diversity was altered by the fire treatments applied. Total species richness was significantly lower in the unburnt plots $\left(F_{4,17}=7.55\right.$, $P<0.01$; Fig. 1a) but similar in other treatments. years) between fires became shorter $\left(F_{4,17}=12.13\right.$, $P<0.01$, Fig. 1b). Unburnt plots had the lowest number of aliens while those burnt annually had the highest alien richness. The frequency of burning also had a significant effect on the proportion of alien plant species $\left(F_{4,17}=7.94, P<0.01\right.$, one-way ANOVA on arcsine-transformed data). The proportion of aliens was highest in the annually burnt plots followed by plots burnt biennially (Fig. 1c). It was lowest in plots protected from burning for 50 years but did not differ significantly between plots burnt either triennially or quadrennially. Alien richness increased significantly as the interval (in

Response of forbs, graminoids and woody species to frequency of burning

The response of forbs, graminoids and woody species to frequency of burning was variable. Table 1 shows that the number of forbs was significantly greater in plots burnt annually and in plots burnt biennially than in plots burnt quadrennially, triennially, and the unburnt plots. The mean number of graminoids and woody plants was significantly lower in unburnt plots but similar in other treatments.

The proportion of alien species also differed among the three major growth forms examined (i.e. forbs, graminoids, and woody plants). The proportion of alien forbs was greatest in annually burnt plots and least in the unburnt plots, but did not differ significantly between plots burnt quadrennially and triennially (Table 1). Although plots burnt biennially, triennially and quadrennially had been invaded by alien woody plants, the proportion of alien woody plants did not differ significantly between these treatments $\left(F_{4,17}=\right.$ $0.42, P>0.05$, one-way ANOVA on arcsine-transformed data). The annually burnt plots and those
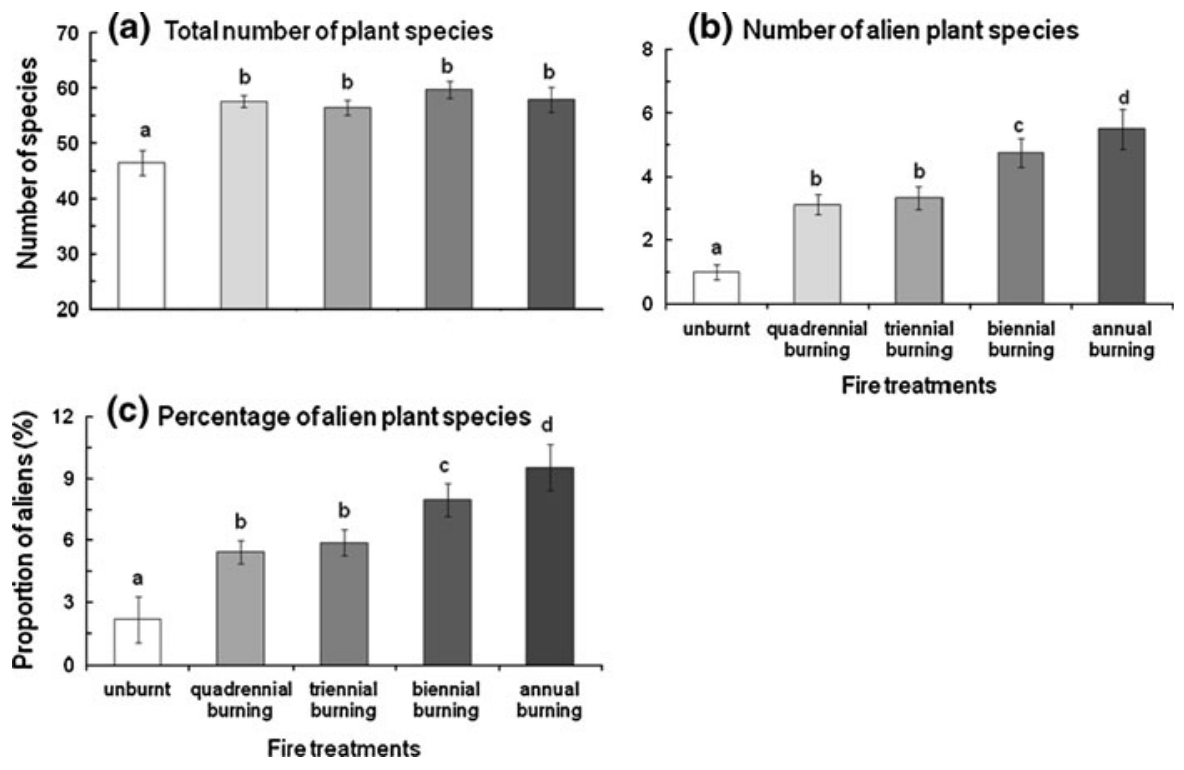

Fig. 1 Effect of fire frequency on a plant diversity, b alien richness, and $\mathbf{c}$ proportion of alien plants at a mesic savanna site (Grasslands Research Station, Zimbabwe). Experimental plots were exposed to different fire treatments for half a century. Data presented are means \pm S.E. Means with different letters are significantly different at $P<0.05$ with a Tukey's
HSD multiple comparison test. All analyses were based on logtransformed data for the number of species and arcsinetransformed data for the proportion of alien species but untransformed data are presented to make comparisons between treatments easier 
Table 1 Number of forbs, graminoids and woody species in plots after more than 50 years of experimental burning to assess impact of fire frequency on vegetation structure and composition at Marondera Grasslands Research Station, Zimbabwe

\begin{tabular}{lccrrr}
\hline Growth form & \multicolumn{3}{l}{ Fire treatments } & & \\
\cline { 2 - 6 } & Unburnt & Quadrennial burning & Triennial burning & Biennial burning & Annual burning \\
\hline Forbs & $23 \pm 2.0^{\mathrm{a}}$ & $25 \pm 1.0^{\mathrm{a}}$ & $26 \pm 1.2^{\mathrm{a}}$ & $29 \pm 2.0^{\mathrm{b}}$ & $31 \pm 1.4^{\mathrm{b}}$ \\
$\quad$ Alien forbs & $4.5 \pm 2.1^{\mathrm{a}}$ & $10.8 \pm 1.0^{\mathrm{b}}$ & $11.0 \pm 1.2^{\mathrm{b}}$ & $13.9 \pm 1.5^{\mathrm{c}}$ & $19.6 \pm 2.1^{\mathrm{d}}$ \\
Graminoids & $10 \pm 1.7^{\mathrm{a}}$ & $14 \pm 0.8^{\mathrm{b}}$ & $14 \pm 1.0^{\mathrm{b}}$ & $13 \pm 1.2^{\mathrm{b}}$ & $13 \pm 1.7^{\mathrm{b}}$ \\
Woody plants & $15 \pm 0.6^{\mathrm{a}}$ & $18 \pm 0.3^{\mathrm{b}}$ & $17 \pm 0.4^{\mathrm{b}}$ & $18 \pm 0.4^{\mathrm{b}}$ & $17 \pm 0.6^{\mathrm{b}}$ \\
$\quad$ Alien woody plants & 0 & $0.7 \pm 0.5^{\mathrm{a}}$ & $0.3 \pm 0.4^{\mathrm{a}}$ & $0.8 \pm 0.5^{\mathrm{a}}$ & 0 \\
\hline
\end{tabular}

For forbs and woody species, the percentage of aliens is shown. No alien grasses were found in experimental plots. Values presented are means \pm S.E. Within each growth form (row), means with different letters are significantly different across fire treatments at $P<0.05$ with a Tukey HSD multiple comparison test. All analyses were based on log-transformed data for the number of species and arcsine-transformed data for the proportion of alien species

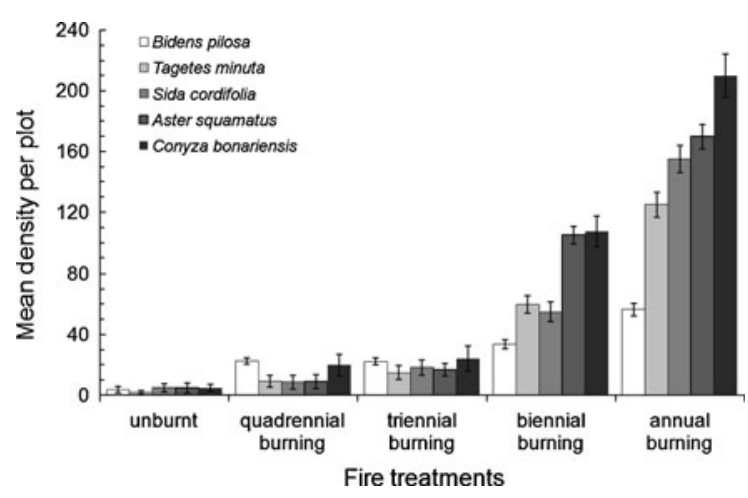

Fig. 2 Mean density ( \pm S.E.) of five common alien forbs in plots exposed to more than 50 years of experimental burning at a mesic savanna experimental site (Grasslands Research Station, Zimbabwe). Density $=$ number of individuals per $\mathrm{m}^{2}$ plot (see text for explanation). All analyses were based on log-transformed data

protected from burning have not been invaded by alien woody plants. Neither alien grasses nor sedges were found in any experimental plot.

Effects of fire on the abundance of alien forbs

Figure 2 shows that the density of all the five alien forbs evaluated significantly increased as the interval (in years) between fires were shortened. In general, the mean density of these common alien forbs in annually burnt plots was at least ten times as high as the mean density of unburnt plots (Table 2).

\section{Discussion}

The results show that half a century of frequent burning of a mesic African savanna promoted the invasion by alien plants relative to fire exclusion. More alien species became established in plots which were frequently burnt than in plots which were protected from burning. Plant diversity was also altered by long-term burning. Overall species richness was significantly higher in the regularly burnt plots compared to unburnt plots. Previous research published on this long-term fire experiment revealed that regular burning reduced tree size regardless of the frequency of burning, but failed to eliminate woody plants, or significantly alter tree species diversity at the experimental site (Furley et al. 2008). Data from another long-term, plot-based and well-reported fire experiment in the Kruger National Park (South Africa) with similar mean annual precipitation to the present study site, also showed fire frequency had no significant effect on tree density (Higgins et al. 2007) as well as woody species richness and composition (Van Wilgen et al. 2007). These previous studies did not evaluate the effect of frequency of burning on alien plant invasions in African savannas and as far as we are aware, no alien species were found at the Kruger experiment (Higgins et al. 2007; Van Wilgen et al. 2007). It may well be that for the Zimbabwean experimental site, many alien species established because the experiment was located at an agricultural research site with a long history of anthropogenic disturbance, specifically pasture improvement. Hence, at the Zimbabwean experimental site, propagule availability of alien taxa may have been higher than at Kruger National Park. The role of propagule availability in enhancing alien invasion success is widely reported in the literature (Edward et al. 2009; Lockwood et al. 2005; Rouget 
Table 2 Mean ( \pm S.E.) of untransformed density (number of plants per $\mathrm{m}^{2}$ ) of five common alien forbs found in plots exposed to different fire treatments for more than 50 years at a mesic savanna site (Grasslands Research Station, Zimbabwe)

\begin{tabular}{llllll}
\hline Alien forb & \multicolumn{2}{l}{ Fire treatments } & & \\
\cline { 2 - 6 } & Unburnt & Quadrennial burning & Triennial burning & Biennial burning & Annual burning \\
\hline Aster squamatus & $5 \pm 3.1^{\mathrm{a}}$ & $17 \pm 4.0^{\mathrm{b}}$ & $9 \pm 4.7^{\mathrm{a}}$ & $105 \pm 5.7^{\mathrm{c}}$ & $170 \pm 8.1^{\mathrm{d}}$ \\
Bidens pilosa & $4 \pm 2.1^{\mathrm{a}}$ & $23 \pm 2.1^{\mathrm{b}}$ & $22 \pm 2.4^{\mathrm{b}}$ & $34 \pm 2.9^{\mathrm{c}}$ & $57 \pm 4.1^{\mathrm{d}}$ \\
Conyza bonariensis & $5 \pm 2.4^{\mathrm{a}}$ & $20 \pm 7.2^{\mathrm{b}}$ & $24 \pm 8.3^{\mathrm{b}}$ & $108 \pm 10.2^{\mathrm{c}}$ & $210 \pm 14.4^{\mathrm{d}}$ \\
Sida cordifolia & $5 \pm 2.7^{\mathrm{a}}$ & $9 \pm 4.5^{\mathrm{a}}$ & $18 \pm 5.2^{\mathrm{b}}$ & $55 \pm 6.3^{\mathrm{c}}$ & $155 \pm 8.9^{\mathrm{d}}$ \\
Tagetes minuta & $2 \pm 1.1^{\mathrm{a}}$ & $9 \pm 4.0^{\mathrm{b}}$ & $15 \pm 4.7^{\mathrm{b}}$ & $60 \pm 5.7^{\mathrm{c}}$ & $125 \pm 8.1^{\mathrm{d}}$ \\
\hline
\end{tabular}

Within a row, means with the same letter do not differ significantly at $P<0.05$ with a Tukey HSD multiple comparison test. All analyses were based on log-transformed data

and Richardson 2003; Von Holle and Simberloff 2005) but the interaction effects of propagule availability and frequency of burning were not explicitly examined in this study.

Frequent burning (i.e. annual and biennial fires) appears to favour forbs in general and also facilitate alien forb invasions. Total forb richness was significantly higher in plots burnt either annually or biennially but it was similar in other treatments. In contrast, the proportion of alien forbs relative to the total number of forbs present consistently increased as the fire interval was shortened. The abundance of common alien forbs also followed a similar pattern. The explanation for this increased performance of alien forbs in plots exposed to regular annual and biennial fires is not clear, but may be attributed to different mechanisms. First, by killing or damaging dominant grass species and suppressing woody plant recruitment and growth (Furley et al. 2008; Van Wilgen et al. 2007), frequent fires may prevent their competitive dominance, thereby creating a window of opportunity for alien forbs to establish (Alpert 2006; Barney and Whitlow 2008; Frost et al. 1985; MacDougall et al. 2009; Shea and Chesson 2002). Second, frequent fires tend to create gaps in a plant assemblage suitable for colonisation by alien species, particularly those small-seeded forbs with high seed production and a relatively short life cycle (Sousa 1984). Finally, reduced competition from dominant resident species may act in concert with increased availability of resources and bare soil to enhance the invadability of frequently burnt mesic savannas by alien forbs. In the blue oak savannas of the southern Sierra Nevada, alien forb response to fire was also linked to increased post-fire availability of bare patches and resources such as light, which are critical for alien recruitment and growth (Keeley et al. 2003). The same mechanism may be operating in mesic savannas, which are frequently burnt. However, the intensity (hotness) of the fire would provide a compounding effect which has not been considered here. It is likely that with the triennial or quadrennial burning, there is more fuel and this would result in a hotter burn compared to annual and triennial burning. This may explain why plots burnt triennially and quadrennially were less vulnerable to invasion by alien plants than plots burnt annually and biennially.

Fire is both inevitable and necessary for maintaining the structure and functioning of mesic savannas (Sankaran et al. 2005; Van Wilgen 2009). Based on current understanding of savanna ecology, managers of mesic savannas often use fire to influence vegetation structure and composition by manipulating the timing and frequency of burning (Barnes 1965; Bond and Keeley 2005; Van Wilgen 2009). Our findings, however, suggest that the presence of invasive alien plants may complicate the use of fire as a tool for managing mesic savanna ecosystems. The evidence presented here suggests that, if fire is completely excluded from a mesic savanna, plant diversity decreases. On the other hand, burning too frequently e.g. once every year or biennially, may promote the spread and dominance of alien species. This raises the question: how frequently and intensely (hotly) should managers burn mesic savannas and woodland reserves in order to minimize the spread of alien plants, while simultaneously maintaining a functioning savanna?

As overall species richness was significantly higher in plots burnt triennially and quadrennially compared to plots protected from burning, and both alien richness and abundance were significantly lower in plots burnt triennially and quadrennially than in 
plots burnt annually and those burnt biennially, burning once every three to 4 years may assist in securing a functioning mesic savanna ecosystem while preventing the spread of alien plants. This recommendation is in accordance with the widely reported mean fire return interval in mesic savannas, which is typically 3 years (Furley et al. 2008). In making this recommendation, however, we are aware of recent evidence that at the landscape scale, it is rainfall availability in the preceding years rather than management policy that largely determines the timing and frequency of fire (Van Wilgen et al. 2007, 2008). However, regular burning is still the most widely used approach for managing savannas despite the on-going debate in ecology regarding whether regular or flexible burning achieves the intended management goals (Bond and Archibald 2003).

\section{Conclusion}

The experimental evidence presented in this paper lead to the conclusion that frequent burning increases the susceptibility of mesic savannas to invasion by alien plants, with short intervals between fires favouring ruderal alien forbs. This is consistent with ecological theory, which predicts that frequent disturbances favour colonisation by short-lived species which are capable of coping with frequent disturbances (Grime 1977; Lavorel et al. 1997). Hence, the frequency of burning is an important factor to consider when managing these ecosystems for conserving biodiversity and reducing the spread of alien plants. Previous research on alien invasion in African savannas focused mostly on invaders with a long life span, ignoring the less conspicuous forbs. This has tended to limit our understanding of the effects of fire on alien plant invasion in these ecosystems.

\footnotetext{
Acknowledgments We are grateful to the Netherlands Organisation for International Co-operation in Higher Education for supporting this study through a graduate fellowship awarded to M. Masocha. We thank Nation Chikumba, Maxwell Muza and Office Busu for field assistance. The role of the team that maintained the fire experiment is also appreciated.
}

Open Access This article is distributed under the terms of the Creative Commons Attribution Noncommercial License which permits any noncommercial use, distribution, and reproduction in any medium, provided the original author(s) and source are credited.

\section{References}

Alpert P (2006) The advantages and disadvantages of being introduced. Biol Invasions 8:1523-1534

Barnes DL (1965) The effects of frequency of burning and mattocking in the control of growth of coppice in Marandellas. Rhodesian J Agric Res 3:55-56

Barney JN, Whitlow TH (2008) A unifying framework for biological invasions: the state factor model. Biol Invasions 10:259-272

Bond WJ, Archibald S (2003) Confronting complexity: fire policy choices in South African savanna parks. Int J Wildland Fire 12:381-389

Bond WJ, Keeley JE (2005) Fire as a global 'herbivore': the ecology and evolution of flammable ecosystems. Trends Ecol Evol 20:387-394

Bond WJ, Midgley JJ (2001) Ecology of sprouting in woody plants: the persistence niche. Trends Ecol Evol 16:45-51

Bond WJ, Woodward FI, Midgley GF (2005) The global distribution of ecosystems in a world without fire. New Phytol 165:525-537

Coates-Palgrave M (2002) Trees of southern Africa. Struik Publishers, Cape Town

Crawley MJ (2002) Statistical computing: an introduction to data analysis using SPLUS. Wiley, Chichester

Edward E, Munishi PKT, Hulme PE (2009) Relative roles of disturbance and propagule pressure on the invasion of humid tropical forest by Cordia alliodora (Boraginaceae) in Tanzania. Biotropica 41:171-178

Frost P, Menaut JC, Walker B, Medina E, Solbrig OT, Swift M (1985) Responses of savannas to stress and disturbance. Biol Int Spec Issue 10:1-82

Furley PA, Rees RM, Ryan CM, Saiz G (2008) Savanna burning and the assessment of long-term fire experiments with particular reference to Zimbabwe. Prog Phys Geogr 32:611-634

Gibbs Russell GE, Watson L, Koekemoer M, Smook L, Barker NP, Anderson HM, Dallawitz MJ (1990) Grasses of southern Africa: an identification manual with keys, descriptions, distributions, classification and automated identification and information retrieval from computerized data. National Botanic Gardens/Botanical Research Institute, South Africa, p 437

Gibson DJ (1988) The relationship of sheep grazing and soil heterogeneity to plant spatial patterns in dune grassland. J Ecol 76:233-252

Glen HF (2002) Cultivated plants of southern Africa. Jacana, Johannesburg, p 428

Govender N, Trollope WSW, Van Wilgen BW (2006) The effect of fire season, fire frequency, rainfall and management on fire intensity in savanna vegetation in South Africa. J Appl Ecol 43:748-758

Grime JP (1977) Evidence for the existence of three primary strategies in plants and its relevance to ecological and evolutionary theory. Am Nat 111:1169-1194

Grundy IM, Campbell BM, Frost PGH (1994) Spatial pattern, regeneration and growth rates of Brachystegia spiciformis and Julbernadia globiflora. Vegetatio 115:101-107

Henderson L (2007) Invasive, naturalized and casual alien plants in southern Africa: a summary based on the 
Southern African Plant Invaders Atlas (SAPIA). Bothalia 37:215-248

Higgins SI, Bond WJ, Trollope WSW (2000) Fire, resprouting and variability: a recipe for grass-tree coexistence in savanna. J Ecol 88:213-229

Higgins SI, Bond WJ, February EC, Bronn A, Euston-Brown DIW, Enslin B, Govender N, Rademan L, O'Regan S, Potgieter ALF, Scheiter S, Sowry R, Trollope L, Trollope WSW (2007) Effects of four decades of fire manipulation on woody vegetation structure in savanna. Ecology 88:1119-1125

Hobbs RJ, Huenneke LF (1992) Disturbance, diversity, and invasion: implications for conservation. Conserv Biol 9:761-770

Keeley JE, Lubin D, Fotheringham CJ (2003) Fire and grazing impacts on plant diversity and alien plant invasions in the southern Sierra Nevada. Ecol Appl 13:1355-1374

Lavorel S, McIntyre S, Landsberg J, Forbes TDA (1997) Plant functional classifications: from general groups to specific groups based on response to disturbance. Trends Ecol Evol 12:474-478

Lockwood JL, Cassey P, Blackburn T (2005) The role of propagule pressure in explaining species invasions. Trends Ecol Evol 20:223-228

MacDougall AS, Gilbert B, Levine JM (2009) Plant invasions and the niche. J Ecol 97:609-615

Mapaura A, Timberlake J (2004) A checklist of Zimbabwean vascular plants. Southern African Botanical Diversity Network Report No. 33. SABONET, Pretoria and Harare

Roques K, O'Connor TG, Watkinson AR (2001) Dynamics of shrub encroachment in an African savanna: relative influences of fire, herbivory, rainfall and density dependence. J Appl Ecol 38:268-280

Rouget M, Richardson DM (2003) Understanding patterns of plant invasion at different spatial scales: quantifying the roles of environment and propagule pressure. In: Child LE, Brock JH, Brundu G, Prach K, Pyšek P, Wade PM, Williamson $\mathrm{M}$ (eds) Plant invasions: ecological threats and management solutions. Backhuys Publishers, Leiden, pp 3-15

Sankaran M, Hanan NP, Scholes RJ, Ratnam J, Augustine DJ, Cade BS, Gignoux J, Higgins SI, Le Roux X, Ludwig F, Ardo J, Banyikwa F, Bronn A, Bucini G, Caylor KK, Coughenour MB, Diouf A, Ekaya W, Feral CJ, February EC, Frost PGH, Hiernaux P, Hrabar H, Metzger KL, Prins HHT, Ringrose S, Sea W, Tews J, Worden J, Zambatis N
(2005) Determinants of woody cover in African savannas. Nature 438:846-849

Savadogo P, Tiveau D, Sawadogo L, Tigabu M (2008) Herbaceous species responses to long-term effects of prescribed fire, grazing and selective tree cutting in the savanna-woodlands of West Africa. Perspect Plant Ecol Evol Syst 10:179-195

Shea K, Chesson P (2002) Community ecology theory as a framework for biological invasions. Trends Ecol Evol 17:170-176

Sousa WP (1984) The role of disturbance in natural communities. Annu Rev Ecol Syst 15:353-391

Strang RM (1974) Some man-made changes in successional trends on Rhodesian highveld. J Appl Ecol 11:249-263

Valery L, Fritz H, Lefeuvre JC, Simberloff D (2008) In search of a real definition of the biological invasion phenomenon itself. Biol Invasions 10:1345-1351

Van Langevelde F, Van de Vijver CADM, Kumar L, Van de Koppel J, De Ridder N, Van Andel J, Skidmore AK, Hearne JW, Stroosnijder L, Bond WJ, Prins HHT, Rietkerk M (2003) Effects of fire and herbivory on the stability of savanna ecosystems. Ecology 84:337-350

Van Oudtshoorn F (2006) Guide to grasses of southern Africa. Briza Publications, Cape Town

Van Wilgen BW (2009) The evolution of fire management practices in savanna protected areas in South Africa. S Afr J Sci 105:343-349

Van Wilgen BW, Govender N, Biggs HC, Ntsala D, Funda XN (2004) Response of savanna fire regimes to changing firemanagement policies in a large African National Park. Conserv Biol 18:1533-1540

Van Wilgen BW, Govender N, Biggs HC (2007) The contribution of fire research to fire management: a critical review of a long-term experiment in the Kruger National Park, South Africa. Int J Wildland Fire 16:519-530

Van Wilgen BW, Govender N, MacFadyen S (2008) An assessment of the implementation and outcomes of recent changes to fire management in the Kruger National Park. Koedoe 50:22-31

Von Holle B, Simberloff D (2005) Ecological resistance to biological invasion overwhelmed by propagule pressure. Ecology 86:3212-3218

Watson PJ, Bradstock RA, Morris C (2009) Fire frequency influences composition and structure of the shrub layer in an Australian subcoastal temperate grassy woodland. Austral Ecology 34:218-232 